\title{
Understanding the endorsement of wife beating in Ghana: evidence of the 2014 Ghana demographic and health survey
}

\author{
Kwamena Sekyi Dickson ${ }^{1 *}$ (D), Edward Kwabena Ameyaw² ${ }^{2}$ and Eugene Kofuor Maafo Darteh ${ }^{1}$ (1)
}

\begin{abstract}
Background: Domestic violence (DV) has become a global burden. The high occurrence of intimate partner violence (IPV) across the globe has implications for the socioeconomic wellbeing and health of children and women.

Methods: Data for the study was from the 2014 Ghana Demographic and Health Survey (GDHS). The association between approval of wife-beating and background characteristics of women was examined by the use of a Binary Logistic Regression model.

Results: A higher proportion of respondents were from urban areas (53.7 and 52.2\% women and men respectively). The ages of women ranged from 15 to 49 (mean $=30, S D=9.7$ ) whilst the age range of men was $15-59$ ( mean $=32$, $\mathrm{SD}=12.5$ ). Twenty-four percent of the men and $23 \%$ of the women were within the richest wealth category. The results showed that few women (6.3\%) and men (11.8\%) had attained higher education. Both women (AOR=1.3; $\mathrm{Cl}=1.01-1.24)$ and men $(\mathrm{AOR}=2.2 ; \mathrm{Cl}=1.72-2.76)$ aged 15-24 had higher odds of approving wife-beating than those aged 35-49 (reference category). Poorest women ( $A O R=2.7 ; C l=2.14-3.38)$ and men ( $A O R=1.7 ; C l=1.11-2.69)$ alike had higher odds of approving wife-beating, as compared with those in the richest wealth status (reference category). As compared to research participants with higher/tertiary education, both women ( $\mathrm{AOR}=5.1 ; \mathrm{Cl}=3.52-7.51)$ and men ( $A O R=4.2 ; \mathrm{Cl}=2.37-7.16)$ without any formal education were found to be at higher odds to approve wife-beating; however, this observation seems to decline as one's educational status advances.

Conclusion: Age, wealth status, level of education, frequency of listening to radio, frequency of reading newspaper/ magazine, frequency of watching television, ethnicity, and religion were found to be significantly associated with Ghanaian men and women's approval of wife-beating. Policies, interventions, and campaigns must target Ghanaians without formal education and young adults on the need to uphold human rights in order to dissuade them from endorsing intimate partner violence. Mass media has also proven to be a protective factor against domestic violence approval and, as such, much progress can be made if utilised by human rights activists, especially through radio, magazine and television broadcasting.
\end{abstract}

Keywords: Endorsing, Wife beating, Ghana, Domestic violence, Intimate partner violence

\footnotetext{
* Correspondence: nadicx@gmail.com

'Department of Population and Health, University of Cape Coast, Cape Coast,

Ghana

Full list of author information is available at the end of the article
}

(c) The Author(s). 2020 Open Access This article is distributed under the terms of the Creative Commons Attribution 4.0 International License (http://creativecommons.org/licenses/by/4.0/), which permits unrestricted use, distribution, and reproduction in any medium, provided you give appropriate credit to the original author(s) and the source, provide a link to the Creative Commons license, and indicate if changes were made. The Creative Commons Public Domain Dedication waiver (http://creativecommons.org/publicdomain/zero/1.0/) applies to the data made available in this article, unless otherwise stated. 


\section{Background}

Domestic violence (DV) has become a global burden [1, 2]. The WHO [2] reported that violence against women constitutes a major public health concern affecting a third of women globally [2]. The high occurrence of intimate partner violence (IPV) against women across the globe and the ensuing socioeconomic costs together with related health implications for women and their children have been documented [3, 4]. Domestic violence (DV) constitutes a pattern of coercive approaches including but not restricted to psychological, physical, social, emotional, sexual, and economic mishandling effected by one person against an intimate partner, usually motivated by the aim of creating and retaining power and or control [5]. Historically, five principal set of issues (male aggression, sociological factors, individual psychological factors, poverty and pervasiveness of beliefs of violence) $[6,7]$ have been advanced to explain the factors allied with intimate partner violence.

As acknowledged by the patriarchy theory, perpetration of domestic violence is reinforced by patriarchal ideologies. In patriarchal societies, males demonstrate superiority and gain control over females [8]. Patriarchy subordinates women and renders them more prone to violence in six main structures namely: patriarchal relations in paid work, patriarchal mode of production, male violence, patriarchal relations in the state, patriarchal relations in sexuality, and patriarchal relations within cultural institutions [9]. In Africa, violence is explained by two main ideologies: the first describing experiences of violence within the family and the second taking into account the changing definitions of domestic violence [10]. Sometimes, it is argued that both men and women experience domestic physical violence; however, women usually experience it most [11].

Studies have stressed individual psychology, male aggression, and interpersonal relationships within families as the dominant factors reinforcing DV [12-14]. Tactics for perpetrating DV include dominance, humiliation, isolation, threat, intimidation as well as denial and blame. The WHO [3] noted that Africa, South-Eastern Asia and the Eastern Mediterranean have the highest prevalence of physical domestic violence, with the least being recorded in Europe and the Western Pacific. Violence perpetration is significant among women in the childbearing age group (15-49 years) - a critical period for maternal health $[15,16]$. Consequently, a couple of responses have been advanced to curtail this phenomenon, including the Declaration on the Elimination of Violence Against Women (DEVAW) and UN Special Rapporteur on Violence Against Women.

In Ghana, physical domestic violence manifests in several dimensions, including slapping or throwing things at someone, pushing, hitting, attacking with a weapon, choking, or strangling [16]. The most common forms of physical violence in Ghana over a lifetime include slaps or being hit with thrown objects, followed by being hit by another person [16]. However, varied implications emerge depending on the specific victim, his/her age, the intensity of the violence, and consistency of torment the person experiences [17]. Living under persistent threat, fear, and humiliation constitute some of the emotional states developed in the memories of victims [17].

Physical domestic violence has several implications for women. Victims are more prone to induced abortion, HIV, depression, and other ill health conditions such as anxieties, phobias, irritable bowel syndrome, and gynecological problems [3]. Women who experience physical domestic violence usually have babies with low birth weight [3]. These and other factors prompted the Ghana government to enact some laws to safeguard the rights and privileges of women and children. Among these are the 1992 Constitution, which prohibits sex-based discrimination, and criminalizes some harmful cultural practices such as widowhood rites. Additionally, the parliament of the Republic of Ghana enacted the Domestic Violence Act (Act 732). Beyond these, other efforts have been initiated over the past years to lessen the incidence of DV. For instance, the first legislative effort of the country acknowledged the intention of the global community in advocating women's rights [18].

In a typical Ghanaian society, a woman's inability to fulfill her gender roles is interpreted as "disobedience" [19]. Instances where a woman deserves to be beaten include denying her husband sex, and failure to execute her household duties [1, 19]. The Ghana Combined CEDAW Report noted that, to a greater extent, women are considered to be inferior, in need of protection, and are to conform to the orders of an authority, usually males, throughout their lifetime [1]. This phenomenon confers so much opportunity for men to chastise women and also consider beating as an effective tool for bringing women to order [1].

Most women are reluctant to report domestic violence due to its acceptance and the belief in women's obligation to succumb to men [16]. In the light of this, domestic violence is considered "normal", thereby hindering institutions from sanctioning culprits [19]. In some instances, women are considered to attract abuse by being independent (because it is assumed to threaten their husband's superiority) and this worsens if the woman's independence offers her the chance to augment her husband's income [20]. Studies on IPV in Ghana have either focused on emotional violence [21] or are limited to the views of women alone [22-24]. These studies have not considered the main perpetrators of violence, men. As such, there is the need to fill this literature gap. This paper, therefore, contributes to the literature by examining the drivers deepening the endorsement of wife beating among both males and females in Ghana. 


\section{Methods \\ Data}

The data for the study was obtained from both men's and women's files from the 2014 Ghana Demographic and Health Survey. The Demographic and Health Survey (DHS) captures data on various aspects of women's health and wellbeing, including issues of physical domestic violence. The survey is a nationwide survey, with a representative sample of 9396 women and 4388 men aged 15-49 and 15-59 respectively. However, the actual samples for this study were 9387 and 4387 for women and men respectively due to non-response. The 2014 GDHS was conducted using an updated frame from the 2010 Population and Housing Census, which was prepared by the Ghana Statistical Service (GSS). The survey followed a two-stage sample design in order to allow estimates of core indicators at the national level. The first phase constituted a selection of sample points (clusters) involving enumeration areas (EAs) which were outlined for the $2010 \mathrm{PHC}$ in which 427 clusters were designated constituting 216 from urban and 211 from rural areas. The second stage utilised systematic sampling of households, in which household inventory operation was conducted in all the identified EAs. Afterward, the households considered for the survey were selected from the list randomly [22].

\section{Definition of variables}

Approval or justification of wife-beating was the outcome variable. Justification of a husband to beat the wife was asked under five conditions: if wife burns the food; if wife neglects the children; if wife argues with husband; if wife goes out without telling the husband; and if wife refuses to have sex with the husband. All these were asked as yes $=1$ or no $=0$. An index was created with all the "yes" and "no" answers, with scores ranging from 0 to 5 . The score 0 was labelled as "not approve" and 1 to 5 was labelled as "approve" [23, 24]. A dummy variable was generated with ' 0 ' score being respondents who do not approve of wife-beating and ' 1 ' being respondents who approve at least one of the five questions justifying wife-beating.

The explanatory variables were age, residential status, wealth, education, religion, and ethnicity. Inclusion of religion and ethnicity was as a result of inconsistencies in arguments about their influence on the approval of domestic violence in the literature [23, 25]. Additionally, some behavioural factors were considered and these are the frequency of listening to radio, frequency of reading newspaper/ magazine, and frequency of watching television. These behavioural factors were considered because campaigns against domestic violence in the country are communicated through these various channels. Also, some variables were recoded in order to ensure clarity of the results. With this, religion was recoded as Christian $=1 ; \quad$ Islam $=2 ; \quad$ Traditional $/$ spiritual $=3 ; \quad$ Other $=4$. Age was also recoded into $15-24=1 ; 25-34=2 ; 35-$ $49=3$ and $50-59=4$.

\section{Data analysis}

Data analysis was carried out using STATA version 13. Since the outcome variable was dummy, binary logistic regressions were conducted. Two models were constructed in all; Model 1 and 2 report for females and males respectively. They looked at the combined effect of socio-demographic variables and behavioural factors on approval or justification for wife-beating. Survey weights were factored into both descriptive and inferential analyses in order to offset the challenges of underand over-sampling which are usually associated with national surveys. Specifically, the binary logistic regression was employed, given that this technique is more appropriate for dichotomous variables. A key assumption underlying the binary logistic regression model is that the dependent variable should be dichotomous in nature and the data should not have any outlier.

\section{Results \\ Descriptive results}

More than half of the respondents reside in urban areas (53.7 and 52.2\% women and men respectively) as indicated in Table 1 . The ages of women ranged from 15 to 49 (mean $=30, \mathrm{SD}=9.7)$ whilst the age range of men was $15-59$ (mean $=32, \mathrm{SD}=12.5)$. Significant proportions of both women (23.4\%) and men (24.2\%) were within the richest wealth category. The results showed that few women $(6.3 \%)$ and men $(11.8 \%)$ had attained higher education. As noted in the 2010 Population and Housing Census that Christianity is the leading religion in Ghana [26, 27], the study found that most women (80.1\%) and men (72.5\%) were Christians.

As indicated in Table 2, wife-beating is justified: if wife goes out without telling the husband (females $16.5 \%$ and males 6.6\%); if wife neglects the children (females $21.0 \%$ and males $8.2 \%$ ); if wife argues with husband (females $15.5 \%$ and males $5.9 \%$ ); if wife refuses to have sex with husband (females $12.8 \%$ and male $4.8 \%$ ); and if wife burns food (females $7.4 \%$ and males $2.8 \%$ ).

\section{Multivariate logistic regression results}

As illustrated in Table 3, Model 1 is a combination of sociodemographic and behavioural factors and approval of wifebeating among females. Model 2 also looked at how sociodemographic and behavioural factors predicted the approval of wife-beating among males. With regard to the sociodemographic characteristics, both women $(\mathrm{AOR}=1.4 ; \mathrm{CI}=$ 1.19-1.52) and men (AOR = 2.2; CI = 1.70-2.74) aged 15-24 had higher odds of approving wife-beating than those aged 
Table 1 Background characteristics of respondents

\begin{tabular}{|c|c|c|c|c|}
\hline \multirow[t]{2}{*}{ Explanatory Variable } & \multicolumn{2}{|c|}{ Females $(n=9387)$} & \multicolumn{2}{|c|}{ Males $(n=4387)$} \\
\hline & $\%$ & $\mathrm{~N}$ & $\%$ & $\mathrm{~N}$ \\
\hline \multicolumn{5}{|l|}{ Residence } \\
\hline Urban & 53.7 & 5043 & 52.1 & 2285 \\
\hline Rural & 46.3 & 4344 & 47.9 & 2102 \\
\hline \multicolumn{5}{|l|}{ Age } \\
\hline $15-24$ & 34.4 & 3233 & 32.9 & 1443 \\
\hline $25-34$ & 31.7 & 2973 & 26.0 & 1141 \\
\hline $35-49$ & 33.9 & 3181 & 29.3 & 1285 \\
\hline $50-59$ & - & - & 11.8 & 518 \\
\hline \multicolumn{5}{|l|}{ Wealth status } \\
\hline Poorest & 16.1 & 1512 & 17.1 & 751 \\
\hline Poorer & 17.4 & 1636 & 17.8 & 779 \\
\hline Middle & 20.6 & 1936 & 19.0 & 835 \\
\hline Richer & 22.5 & 2116 & 21.9 & 960 \\
\hline Richest & 23.4 & 2187 & 24.2 & 1062 \\
\hline \multicolumn{5}{|l|}{ Level of Education } \\
\hline No education & 19.1 & 1790 & 10.7 & 470 \\
\hline Primary & 17.8 & 1670 & 13.5 & 590 \\
\hline Secondary & 56.8 & 5331 & 64.0 & 2809 \\
\hline Higher/tertiary & 6.3 & 596 & 11.8 & 518 \\
\hline \multicolumn{5}{|l|}{ Religion } \\
\hline Christian & 80.1 & 7524 & 72.5 & 3182 \\
\hline Islam & 15.2 & 1421 & 17.6 & 771 \\
\hline Traditional/spiritual & 2.0 & 191 & 3.7 & 164 \\
\hline Other & 2.7 & 251 & 6.2 & 270 \\
\hline \multicolumn{5}{|c|}{ Frequency of reading newspaper/magazine } \\
\hline Not at all & 81.1 & 7615 & 64.7 & 2837 \\
\hline Less than once a week & 10.2 & 956 & 17.9 & 785 \\
\hline At least once a week & 8.7 & 816 & 17.4 & 765 \\
\hline \multicolumn{5}{|l|}{ Frequency of listening to radio } \\
\hline Not at all & 15.6 & 1468 & 5.5 & 242 \\
\hline Less than once a week & 32.1 & 3017 & 16.1 & 708 \\
\hline At least once a week & 52.3 & 4902 & 78.4 & 3437 \\
\hline \multicolumn{5}{|c|}{ Frequency of watching television } \\
\hline Not at all & 23.5 & 2203 & 16.8 & 735 \\
\hline Less than once a week & 25.7 & 2415 & 18.8 & 827 \\
\hline At least once a week & 50.8 & 4769 & 64.4 & 2825 \\
\hline \multicolumn{5}{|l|}{ Ethnicity } \\
\hline Akan & 50.1 & 4701 & 49.0 & 2151 \\
\hline Ga/Dangme & 7.7 & 727 & 9.0 & 393 \\
\hline Ewe & 13.5 & 1265 & 13.6 & 595 \\
\hline Guan & 2.3 & 216 & 2.0 & 87 \\
\hline Mole - Dagbani & 14.8 & 1388 & 14.4 & 630 \\
\hline Grusi & 2.9 & 269 & 2.5 & 112 \\
\hline Gurma & 5.8 & 545 & 5.8 & 255 \\
\hline Mande & 0.9 & 85 & 1.1 & 48 \\
\hline Other & 2.0 & 191 & 2.6 & 116 \\
\hline
\end{tabular}

Computed from 2014 Ghana Demographic and Health Survey
Table 2 Justification of wife beating

\begin{tabular}{|c|c|c|c|c|}
\hline \multirow{2}{*}{$\begin{array}{l}\text { Explanatory } \\
\text { Variable }\end{array}$} & \multicolumn{2}{|c|}{ Females $(N=9387)$} & \multicolumn{2}{|c|}{ Males $(\mathrm{N}=4387)$} \\
\hline & $\%$ & $\mathrm{n}$ & $\%$ & $\mathrm{n}$ \\
\hline \multicolumn{5}{|c|}{ Wife beating justified if wife goes out without telling husband } \\
\hline No & 83.5 & 7838 & 93.4 & 4096 \\
\hline Yes & 16.5 & 1549 & 6.6 & 288 \\
\hline
\end{tabular}

Wife beating justified if wife neglects the children

$\begin{array}{lllll}\text { No } & 79.0 & 7419 & 91.8 & 4027 \\ \text { Yes } & 21.0 & 1968 & 8.2 & 359\end{array}$

Wife beating justified if wife argues with husband

$\begin{array}{lllll}\text { No } & 84.4 & 7919 & 94.1 & 4128 \\ \text { Yes } & 15.6 & 1468 & 5.9 & 258\end{array}$

Wife beating justified if wife refuses to have sex with husband

$\begin{array}{lllll}\text { No } & 87.2 & 8243 & 95.2 & 4177 \\ \text { Yes } & 12.8 & 1144 & 4.8 & 209\end{array}$

Wife beating justified if wife burns food

$\begin{array}{lllll}\text { No } & 92.6 & 8691 & 97.2 & 4265 \\ \text { Yes } & 7.4 & 696 & 2.8 & 121\end{array}$

At least one justification of wife beating

\begin{tabular}{lllll} 
No & 71.7 & 6731 & 87.5 & 3838 \\
Yes & 28.3 & 2656 & 12.5 & 548 \\
\hline
\end{tabular}

Computed from 2014 Ghana Demographic and Health Survey

$35-49$ (reference category). Women with poorest $(\mathrm{AOR}=$ 2.2; $\mathrm{CI}=1.77-2.86)$ and poorer $(\mathrm{AOR}=2.2 ; \mathrm{CI}=1.77-2.86)$ wealth statuses and men with richer wealth status $(\mathrm{AOR}=$ 1.5; $\mathrm{CI}=1.01-2.20)$ had higher odds of approving wifebeating, as compared with those in the richest wealth status (reference category). As compared to research participants with higher/tertiary education, both women $(\mathrm{AOR}=4.3 ; \mathrm{CI}=$ 2.89-6.27) and men ( $\mathrm{AOR}=3.0 ; \mathrm{CI}=1.71-5.36)$ without any formal education were found to have the highest odds of approving wife-beating.

When compared with Christians, women from Islam religion $(\mathrm{AOR}=1.7 ; \mathrm{CI}=1.41-1.91)$ were more likely to approve wife-beating. A similar observation was made among men affiliated to other religious denominations $(\mathrm{AOR}=1.6 ; \mathrm{CI}=1.13-2.15)$ (see Table 3$)$. Women who listened to radio less than once a week $(\mathrm{AOR}=0.7 ; \mathrm{CI}=$ 0.64-0.85) had lesser odds of approving wife-beating, as compared with women who do not listen to radio at all. It was also realised that women who read newspapers/ magazines at least once a week had less tendency of approving wife-beating ( $\mathrm{AOR}=0.6 ; \mathrm{CI}=0.47-0.78$ ). Also, women who watched television at least once a week $(\mathrm{AOR}=0.8 ; \mathrm{CI}=0.71-0.92)$ had lesser odds of approving wife-beating.

\section{Discussion}

The study examined the approval of wife-beating in Ghana from the perspectives of women and men. This 
Table 3 Binary regression on approval of wife beating

\begin{tabular}{|c|c|c|}
\hline \multirow[t]{2}{*}{ Variables } & Females & Males \\
\hline & Model 1 & Model 2 \\
\hline \multicolumn{3}{|l|}{ Age } \\
\hline $15-24$ & $1.4^{* * *}(1.19-1.52)$ & $2.2^{* * *}(1.70-2.74)$ \\
\hline $25-34$ & 1.0(0.92-1.28) & $1.4^{* *}(1.05-1.77)$ \\
\hline $35-49$ & 1 & 1 \\
\hline $50-59$ & - & 1.0(0.68-1.32) \\
\hline \multicolumn{3}{|l|}{ Residence } \\
\hline Urban & 1 & 1 \\
\hline Rural & 1.0(0.90-1.16) & $1.1(0.87-1.42)$ \\
\hline \multicolumn{3}{|l|}{ Wealth status } \\
\hline Poorest & $2.2^{* * *}(1.77-2.86)$ & $1.3(0.84-2.12)$ \\
\hline Poorer & $2.2^{* * *}(1.77-2.86)$ & $1.4(0.90-2.11)$ \\
\hline Middle & $2.0^{* * *}(1.63-2.40)$ & $1.5^{*}(1.01-2.20)$ \\
\hline Richer & $1.4^{* * *}(1.16-1.69)$ & $1.1(0.75-1.62)$ \\
\hline Richest & 1 & 1 \\
\hline \multicolumn{3}{|l|}{ Education } \\
\hline No education & $4.3^{* * *}(2.89-6.27)$ & $3.0^{* * *}(1.71-5.36)$ \\
\hline Primary & $3.3^{* * *}(2.23-4.82)$ & $2.2^{* *}(1.28-3.92)$ \\
\hline Secondary & $2.7^{* * *}(1.84-3.84)$ & $2.1^{* *}(1.23-3.45)$ \\
\hline Higher/tertiary & 1 & 1 \\
\hline \multicolumn{3}{|l|}{ Ethnicity } \\
\hline Akan & 1 & 1 \\
\hline Ga/dangme & $0.8^{*}(0.61-0.98)$ & $1.1(0.71-1.58)$ \\
\hline Ewe & $0.8^{*}(0.69-0.96)$ & $0.5^{* * *}(0.31-0.66)$ \\
\hline Guan & $1.5^{* *}(1.13-1.97)$ & $1.1(0.64-1.96)$ \\
\hline Mole-dagbani & $0.9(0.79-1.07)$ & $1.1(0.80-1.41)$ \\
\hline Grusi & 1.0(0.78-1.24) & $1.5(0.99-2.27)$ \\
\hline Gurma & $2.5^{* * *}(2.04-3.09)$ & $2.0^{* * *}(1.45-2.84)$ \\
\hline Mande & $0.7(0.43-1.04)$ & $0.7(0.31-1.76)$ \\
\hline Other & $0.9(0.64-1.32)$ & $1.2(0.67-2.25)$ \\
\hline \multicolumn{3}{|l|}{ Religion } \\
\hline Christian & 1 & 1 \\
\hline Islam & $1.7^{* * *}(1.44-1.91)$ & $0.8(0.64-1.08)$ \\
\hline Traditional/spiritual & $1.1(0.83-1.50)$ & $1.2(0.86-1.72)$ \\
\hline Other & $1.1(0.85-1.43)$ & $1.6^{* *}(1.13-2.15)$ \\
\hline \multicolumn{3}{|l|}{ Frequency of listening to radio } \\
\hline Not at all & 1 & 1 \\
\hline Less than once a week & $0.7^{* * *}(0.64-0.85)$ & $1.3(0.64-1.08)$ \\
\hline At least once a week & $0.8^{* * *}(0.69-0.89)$ & $0.9(0.62-1.21)$ \\
\hline \multicolumn{3}{|c|}{ Frequency of reading newspaper/ magazine } \\
\hline Not at all & 1 & 1 \\
\hline Less than once a week & 1.0(0.79-1.15) & $0.9(0.64-1.15)$ \\
\hline At least once a week & $0.6^{* * *}(0.47-0.78)$ & $0.6^{* *}(0.39-0.80)$ \\
\hline
\end{tabular}

Table 3 Binary regression on approval of wife beating (Continued)

\begin{tabular}{lll}
\hline Variables & $\begin{array}{l}\text { Females } \\
\text { Model 1 }\end{array}$ & $\begin{array}{l}\text { Males } \\
\text { Model 2 }\end{array}$ \\
\hline $\begin{array}{l}\text { Frequency of watching television } \\
\text { Not at all }\end{array}$ & 1 & 1 \\
Less than once a week & $0.9^{*}(0.74-0.98)$ & $0.9(0.70-1.18)$ \\
At least once a week & $0.8^{* *}(0.71-0.92)$ & $0.8^{*}(0.59-0.98)$ \\
\hline
\end{tabular}

Computed from 2014 Ghana Demographic and Health Survey

$p<0.05^{*} p<0.01^{* *} p<0.001^{* * *}$

study is of much essence, considering the increasing reported rates of domestic physical violence in the country $[28,29]$. Previous evidence suggests that accepting or being permissive toward violence contributes positively toward its perpetration [30]. Meanwhile, little has been documented about the perception of Ghanaians on approval of the phenomenon. Generally, no much variation existed among men and women in terms of their approval of wife-beating (age, wealth status, and education); however, inconsistent results were observed in some instances (such as religion).

This study has observed high inclination of both young men and women toward the approval of wife-beating in Ghana. Possible explanations might include their adherence to cultural tenets [31, 32]. However, the older ones may hold a contrary view due to their experiences about the implications of violence over the years which the younger ones may not be aware of. There has been an inconsistent argument in the literature concerning age and approval of domestic physical violence. Whilst the study contradicts findings that report a low tendency of approval among young adults [33, 34], it is consistent with evidence suggesting otherwise [35].

In terms of wealth, poor men and women approved wife-beating. Having a significant proportion of poor women to approve domestic physical violence might be as a result of their dependence on their husbands for livelihood [24, 36]. When someone depends on somebody for a livelihood, the dependant is more likely to accept and interpret almost all actions of the independent person as acceptable, even if the actions are detrimental to the wellbeing of the dependant [37]. Also, poor men might consider wife-beating as a strategy of easing the psychological trauma induced by their low wealth standing [38]. When men are consistently unable to contend the financial burden of their families, they can be frustrated and irritated at the least provocation and, as a result, such men might consider perpetration of physical violence as a strategy for easing the burden mounted by their economic situation $[39,40]$. Some studies in sub-Saharan Africa have made a similar observation by noticing a 
substantial association between financial reliance and physical violence [23, 24, 34, 41, 42].

Education has been noted to subside the tendency of someone to approve wife-beating. Education promotes autonomy and liberation from suppression [23]. Similar findings have been revealed in other countries [25, 43, 44]. Again, an earlier study has also indicated that Ghanaians without any formal education, especially females, are more probable to support violent ideologies. This, therefore, suggests that formal education is essential if approval of violence perpetration can decline in Ghana.

The study revealed that women having exposure to mass media (radio, newspaper/magazine, and television) were less likely to approve wife-beating. However, men who listened to radio had a higher tendency to approve wife-beating, as compared to men who did not listen to radio. This shows that exposure to mass media (radio) has varied implications on perception about domestic violence approval among men and women. The finding is not surprising in light of the fact that most women stay home and interact with mass media all day whilst men leave for work. The long stay at home creates a conducive environment for women to enhance their depth of knowledge on the implications of physical violence because they tend to have much information from mass media than men.

\section{Conclusion}

In conclusion, females justify wife-beating than males. Age, wealth status, level of education, frequency of listening to radio, frequency of reading newspaper/magazine, frequency of watching television, ethnicity, and religion were found to be significantly associated with Ghanaian men and women's approval of wife-beating. Policies, interventions, and human right campaigns must target Ghanaians without primary educational status and young adults on the need to uphold human rights in order to dissuade them from endorsing intimate partner violence. Mass media has also proven to be a protective factor against domestic violence approval and, as such, much progress can be made if utilised by human rights activists, especially radio/magazine and television broadcasting. Again, rural Ghanaian adults must be targeted in order to achieve holistic improvement in the reduction of domestic physical violence, particularly wifebeating.

\section{Abbreviations}

CHRAJ: Commission for Human Rights and Administrative Justice; DEVAW: Declaration on the Elimination of Violence Against Women; DHS: Demographic and Health Survey; DOWSU: Domestic Violence and Victim Support Unit; DV: Domestic Violence; IPV: Intimate Partner Violence; UN: United Nations; WHO: World Health Organization

\section{Acknowledgments}

The authors would like to acknowledge IFC Macro International for granting us permission to use data. We are also grateful to Mr. Ebenezer Agbaglo of the Department of English, University of Cape Coast, who proofread this manuscript.

\section{Authors' contributions}

The study was conceived by KSD, EKA and EKMD. KSD performed and designed the analysis for the study. EKMD, EKA, and KSD designed the methods for the study. EKA, EKMD, and KSD developed the initial draft of the manuscript. EKMD, EKA, and KSD reviewed the manuscript. All three authors have read and approved this version to be published; they have also agreed to be accountable for all aspects of the work in ensuring that questions related to the accuracy or integrity of any part of the work are appropriately investigated and resolved.

Funding

No specific funding was provided for the study.

Availability of data and materials

The report and dataset are freely available to the public at wuw.measuredhs.com upon request and submission of a consent paper.

\section{Ethics approval and consent to participate}

A concept paper was sent to measure DHS and approval and access was granted us to use the raw data. Since we used secondary data, consent to participate was not applicable.

Consent for publication

Not applicable.

\section{Competing interests}

The authors declare that they have no competing interests.

\section{Author details}

'Department of Population and Health, University of Cape Coast, Cape Coast, Ghana. ${ }^{2}$ The Australian Centre for Public and Population Health Research, Faculty of Health, University of Technology Sydney, Sydney, NSW, Australia.

Received: 7 November 2018 Accepted: 6 February 2020

Published online: 11 February 2020

\section{References}

1. Cantalupo N, Martin LV, Pak K, Shin S. Domestic Violence in Ghana: The Open Secret. Georgetown Public Law and Legal Theory Research Paper No. 10-56. 2010. Retrieved from https://www.google.com/url?sa=t\&rct=j\&q= \&esrc $=s \&$ source $=$ web\& $c d=1 \& c a d=r j a \& u a c t=8 \& v e d=$ 2ahUKEwiVOpblvMTnAhVsDWMBHQJyBxQQFjAAegQ|AxAB\&url=https\%3A\%2 F\%2Fscholarship.law.georgetown.edu\%2Fcgi\%2Fviewcontent.cgi\%3 Farticle\%3D1432\%26context\%3Dfacpub\&usg=AOvVaw2h_OTQKKc5 urnY9Ra1ov6. Accessed 29 Nov 2019.

2. World Health Organization. Global and regional estimates of violence against women: prevalence and health effects of intimate partner violence and non-partner sexual violence. Geneva: WHO Press, World Health Organization; 2013.

3. Campbell J, Jones AS, Dienemann J, Schollenberger J, O'Campo P, Gielen $A C$, et al. Intimate partner violence and physical health consequences. Arch Intern Med. 2002;162:1157-63.

4. Sunita K, Bradley SEK. Women's and Men's experience of spousal violence in two African countries: does gender matter? DHS analytical studies no. 27. Calverton: ICF International; 2012.

5. Siemieniuk RAC, Krentz HB, Gish JA, Gill MJ. Domestic Violence Screening: Prevalence and Outcomes in a Canadian HIV Population. AIDS Patient Care and STDs. 2010:24(12):763-70.

6. Bowman CG, Schneider EM. Feminist legal theory, feminist lawmaking,and the legal profession. Fordham L Rev. 1998;1998(67):249.

7. Schneider EM. Battered women and feminist lawmaking. New Haven: Yale University Press; 2000.

8. Jansson PM. An explorative integration of factors causing Men's violence against women. J Psychol Clin Psychol. 2017:8(2):2-11.

9. Walby S. Theorising patriarchy. Oxford: Blackwell; 2003. 
10. Burrill E, Roberts R, Thornberry E. Domestic Violence and the Law in Colonial and Postcolonial Africa. 2010. Retrieved from https://www. ohioswallow.com/book/Domestic+Violence+and+the+Law+in+Colonial+ and+Postcolonial+Africa. Accessed 29 Nov 2019.

11. Ali PA, Naylor PB. Intimate partner violence: a narrative review of the feminist, social and ecological explanations for its causation. Aggress Violent Behav. 2013;18:611-9.

12. Gosselin DK. Heavy hands: an introduction to the crimes of domestic violence. Upper Saddle River: Prentice Hall; 2000.

13. Pollack RA. An intergenerational model of domestic violence. J Popul Econ. 2004;17:311-29.

14. Heath R. Women's Access to Labor Market Opportunities, Control of Household Resources, and Domestic Violence: Evidence from Bangladesh. World Dev. 2014;57(C):32-46.

15. Pool MS, Otupiri E, Owusu-Dabo E, de Jonge A, Agyemang C. Physical Violence during Pregnancy and Pregnancy Outcomes in Ghana. BMC Pregnancy Childbirth. 2014;14(1):71.

16. Institute of Development Studies (IDS), Ghana Statistical Services (GSS) and Associates. Domestic Violence in Ghana: Incidence, Attitudes, Determinants and Consequences. Brighton: IDS; 2016.

17. Chhikara P, Jakhar J, Malik A, Singla K, Dhattarwal SK. Domestic Violence: The Dark Truth of Our Society. J Indian Acad Forensic Med. 2013;35:1.

18. Cook RJ. Human rights of women: national and international perspectives. Philadelphia: University of Pennsylvania Press; 2011.

19. Adu-Gyamfi E. Challenges undermining domestic violence victims' access to justice in the Mampong municipality of Ghana. J Law Policy Globalization. 2014;27:75-90

20. Murray S. Why doesn't she just leave? Belonging, disruption, and domestic violence. Women's Stud Int Forum. 2008:31(1):65-72.

21. Darteh EKM, Amo-Adjei J. Prevalence and correlates of emotional violence among Ghanaian women. J Arts Soc Sci. 2015;1(1):128-46.

22. Amoakohene MI. Violence against women in Ghana: a look at women's perceptions and review of policy and social responses. Soc Sci Med. 2004; 59(11):2373-85.

23. Doku DT, Asante KO. Women's approval of domestic physical violence against wives: analysis of the Ghana demographic and health survey. BMC Womens Health. 2015;15:120

24. Adjah ES, Agbemafle I. Determinants of domestic violence against women in Ghana. BMC Public Health. 2016;16, 368(1-9). https://doi.org/10.1186/ s12889-016-3041-X

25. Conroy AA. Gender, power, and intimate partner violence: a study on couples from rural Malawi. J Interpers Violence. 2014;29(5):866-88.

26. Ghana Statistical Service (GSS). 2010 population and housing census: National analytical report. Accra: GSS; 2013.

27. Dickson KS, Darteh EKM, Kumi-Kyereme A. Providers of antenatal care services in Ghana: evidence from Ghana demographic and health surveys 1988-2014. BMC Health Serv Res. 2017;17(203):1-9. https://doi.org/10.1186/ s12913-017-2145-z

28. Knott S. (2019). Women in Ghana March Against Sexual Violence. Retrieved from https://www.voanews.com/africa/women-ghana-march-against-sexualviolence. Accessed 29 Nov 2019.

29. Campbell, J. (2016). Violence against Women in Ghana: Unsafe in the Second Safest Country in Africa. Retrieved from https://www.cfr.org/blog/ violence-against-women-ghana-unsafe-second-safest-country-africa. Accessed 29 Nov 2019

30. Chirwa ED, Sikweyiya Y, Addo-Lartey AA, Ogum Alangea D, Coker-Appiah D, Adanu $\mathrm{R}$, Jewkes R. Prevalence and risk factors of physical or sexual intimate violence perpetration amongst men in four districts in the central region of Ghana: baseline findings from a cluster randomised controlled trial. PLOS One. 2018;13(3):e0191663. https://doi.org/10.1371/journal.pone.0191663.

31. Ajayi LA, Soyinka-Airewele P. Key triggers of domestic violence in Ghana: a victim centered analysis. Afr Popul Stud. 2018;32(1):4097-108.

32. Adjei SB. The social intentionality of battered women's agency in Ghana. Psychol Dev Soc. 2018;30(1):1-18.

33. Stickley A, Kislitsyna O, Timofeeva I. Vågerö. Attitudes toward intimate partner violence against women in Moscow. Russia J Fam Violence. 2008; 23(6):447-56.

34. Uthman OA, Lawok S, Moradi T. Factors associated with attitudes towards intimate partner violence against women: a comparative analysis of 17 subSaharan countries. BMC Int Health Hum Right. 2009;9(1):14.
35. Waltermaurer E, Butsashvili M, Avaliani N, Samuels S, McNutt LA. An examination of domestic partner violence and its justification in the republic of Georgia. BMC Womens Health. 2013;13:44.

36. Vyas $S$, Jansen HAFM. Unequal power relations and partner violence against women in Tanzania: a cross-sectional analysis. BMC Womens Health. 2018; 18:185.

37. Dhungel S, Dhungel P, Dhital SR, Stock C. Is economic dependence on the husband a risk factor for intimate partner violence against female factory workers in Nepal? BMC Womens Health. 2017;17(1):82.

38. Fulu E, Warner X, Miedema S, Jewkes R, Roselli T, Lang J. Why do some men use violence against women and how can we prevent it? Quantitative findings from the United Nations multi-country study on men and violence in Asia and the Pacific. Bangkok: UNDP, UNFPA, UN Women and UNV; 2013.

39. Barker G, Aguayo F, Correa P. Understanding men's violence against women: findings from the IMAGES survey in Brazil, Chile and Mexico. Rio: Promundo; 2013.

40. Gupta T, Samuels F. Literature review of male perpetrators of intimate partner violence in South Asia. Overseas Development Institute; 2017 Retrieved from https://www.odi.org/publications/10799-literature-reviewmale-perpetrators-intimate-partner-violence-south-asia. Accessed 29 Nov 2019.

41. Ahinkorah BO, Dickson KS, Abdul-Aziz S. Women decision -making capacity and intimate partner violence among women in sub - Saharan Africa. Arch Public Health. 2018;76(5):1-10. https://doi.org/10.1186/s13690-018-0253-9.

42. Darteh EKM, Doku DT, Esia-Donkoh K. Reproductive health decision making among Ghanaian women. Reprod Health. 2014;11:23. https://doi.org/10. 1186/1742-4755-11-23.

43. Antai DE, Antai JB. Attitudes of women toward intimate partner violence: a study of rural women in Nigeria. Rural Remote Health. 2008:8:996.

44. Hindin MJ. Adolescent child bearing and women's attitudes towards wife beating in 25 Sub-Saharan African countries. Matern Child Health J. 2008; 18(6):1488-95.

\section{Publisher's Note}

Springer Nature remains neutral with regard to jurisdictional claims in published maps and institutional affiliations.

Ready to submit your research? Choose BMC and benefit from:

- fast, convenient online submission

- thorough peer review by experienced researchers in your field

- rapid publication on acceptance

- support for research data, including large and complex data types

- gold Open Access which fosters wider collaboration and increased citations

- maximum visibility for your research: over $100 \mathrm{M}$ website views per year

At $\mathrm{BMC}$, research is always in progress.

Learn more biomedcentral.com/submissions 